\title{
MISCELLANEA
}

\section{Some Enquiries into the Toxicology of Zinc Stearate}

\section{H. E. HARDING}

\author{
From the Department of Pathology, Salisbury General \\ Hospital
}

(RECEIVED FOR PUBLICATION OCTOBER 23, 1957)

At the International Congress of Industrial Medicine in Naples (Noro and Uotila, 1954), it was stated that " the inhalation of zinc stearate dust is known as a cause of pneumonia in children, but its effects in the working environment are not so well known. The authors describe the fatal case of a worker employed for 29 years in a rubber plant. Clinical examination and necropsy showed diffuse fibrosis of the lungs. Histological tests for zinc were positive". These authors (Uotila and Noro, 1957) have since given some further details of their patient, who was first seen by them in July, 1952, after having spent 29 years as a rubber cutter using zinc stearate powder in his work. From the autumn of 1951 he had increasing dyspnoea on exertion, cough, and much sputum. When examined, his general condition was considered fairly good, he had a desquamative dermatitis, clubbed fingers, and "watch-glass" nails. A radiograph of the chest showed slight thickening of the left pleura diminishing towards the apex; small nodules radiating from the hilum; emphysema on the right side posteriorly; and enlarged hilar shadows that were considered to be vascular and not lymphoid. A diagnosis of "pneumoconiosis with probable heart failure" was made. He was in hospital for two further periods and died in June, 1954, approximately two years after he was first examined and after his last exposure to dust. At necropsy the lungs were more fleshy than normal, especially the upper lobes, but without calcification or fibrous bands; the lower lobes showed slight oedema: each ventricle of the heart was $8 \mathrm{~mm}$. thick: the liver was granular and there was ascites. Histological examination of the lungs showed old bleeding and a notable increase of connective tissue with abundant chronic inflammation in which were foreign-body giant cells. A test for zinc showed numerous granules and needles in the connective tissue that contained the metal.

In 1925 a committee on accidents from zinc stearate dusting powders appointed by the Board of Trustees of the American Medical Association reported that as the result of a questionnaire they had received reports of 131 cases of poisoning, 28 of which had terminated fatally. They had also heard of many others unofficially. They recommended that all manufacturers of zinc stearate powders for infants should use a self-closing container of a type which does not lend itself to manipulation by an infant, and should place a uniform caution label on the container. They also recommended that the use of zinc stearate as a dusting powder for infants should be discouraged by the medical profession because of lack of therapeutic evidence of its value. Murray (1926), in recording 60 cases of drug poisoning in infants, stated that one fatality, out of a total of three cases, resulted from the aspiration and ingestion of zinc stearate powder. A baby of 14 months was taken to hospital immediately, she developed a diffuse bronchopneumonia next day, and died in less than a further 24 hours. No record of poisoning by zinc stearate powder has been found in the British literature, and none of the many British paediatricians who have been asked has heard of babies suffering from pneumonia due to this powder.

Zinc stearate is used commercially as a substitute for talc in the rubber tyre industry to prevent adhesion. H.M. Factory Department has no evidence that any disability has been caused by its use, but I know of no examinations for possible harmful effects. Stearate kindly supplied by the management of a rubber tyre company was used in the experiments described here.

\section{Experimental}

Zinc stearate powder was suspended in tap water and autoclaved. Approximately $100 \mathrm{mg}$. of the powder suspended in $1 \mathrm{ml}$. water was injected into the lungs through the larynx of six rats anaesthetized with ether. All the animals died within 10 minutes. Approximately $100 \mathrm{mg}$. was injected into the peritoneal cavity of six cavies. All the animals became rapidly unwell and two died within a few hours: the others appeared quite normal next day and remained so until they were killed at intervals up to 35 days. All but one, killed at the latest date, showed small granulomata in the peritoneum. Examination of the suspension showed that the stearate was difficult to keep suspended in water, and the fluid was notably acid. All further experiments were therefore done with zinc stearate suspended and autoclaved in a mixture of skimmed milk and saline, and the dose was halved.

Fifty rats were given approximately $50 \mathrm{mg}$. of zinc stearate suspended in $1 \mathrm{ml}$. and injected into the lungs through the larynx under ether anaesthesia. Twenty animals died within less than 24 hours, most of them within an hour. Those that were examined showed severe oedema and congestion of the lungs and sometimes small haemorrhages. Animals that survived more than 24 hours appeared quite normal until the time they were killed. Animals killed seven days after injection showed small cellular islands of histiocytes scattered through the lungs. None of the injected dust was visible 


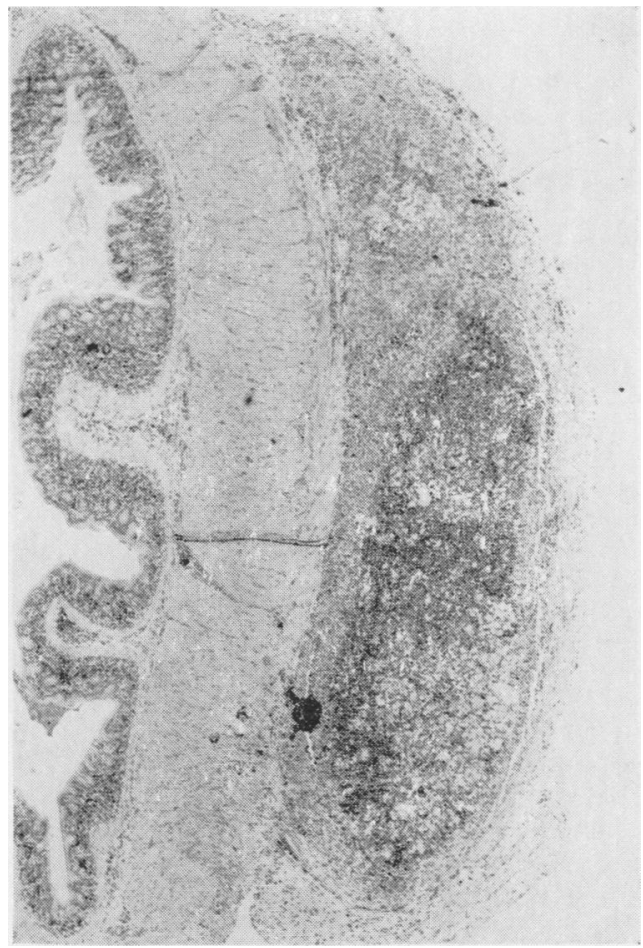

Fig. 1.-Peritoneal granuloma in cavy after 28 days. Stained with haematoxylin and eosin, $\times 25$ approximately.

in ordinary paraffin sections, but it is possible that some was still present, since it was later found that the stearate is moderately soluble in fat solvents. Animals killed 14 days or longer after the injection showed no abnormality in the lungs. Rats were killed up to 259 days after the injection and in none was any fibrosis detected in the lungs.

Six cavies were given $50 \mathrm{mg}$. suspended in $1 \mathrm{ml}$. water and injected into the peritoneal cavity. None of them showed any apparent ill effects. One animal killed at seven days showed a few small white nodules in the peritoneum that on section had a granulomatous character with a centre of polymorphonuclear leucocytes. After 14 days the stearate lay in a mass of dead cells surrounded by a layer of histiocytes and an outer layer of early fibroblastic proliferation. At 28 days the small granulomata were slightly more defined (Fig. 1). At 42 days a formless or crystalline centre was ringed round by histiocytes outside which was a narrow band of young fibrous tissue (Fig. 2). At 100 and 105 days nothing abnormal was visible in the peritoneum, and no granulomatous or fibrous reaction was found in sections.

\section{Discussion}

From these experiments it appears that zinc stearate in suspension in tap water or in a mixture of skimmed milk and physiological saline is acutely irritant, and in doses of $50 \mathrm{mg}$. kills nearly half the animals if injected

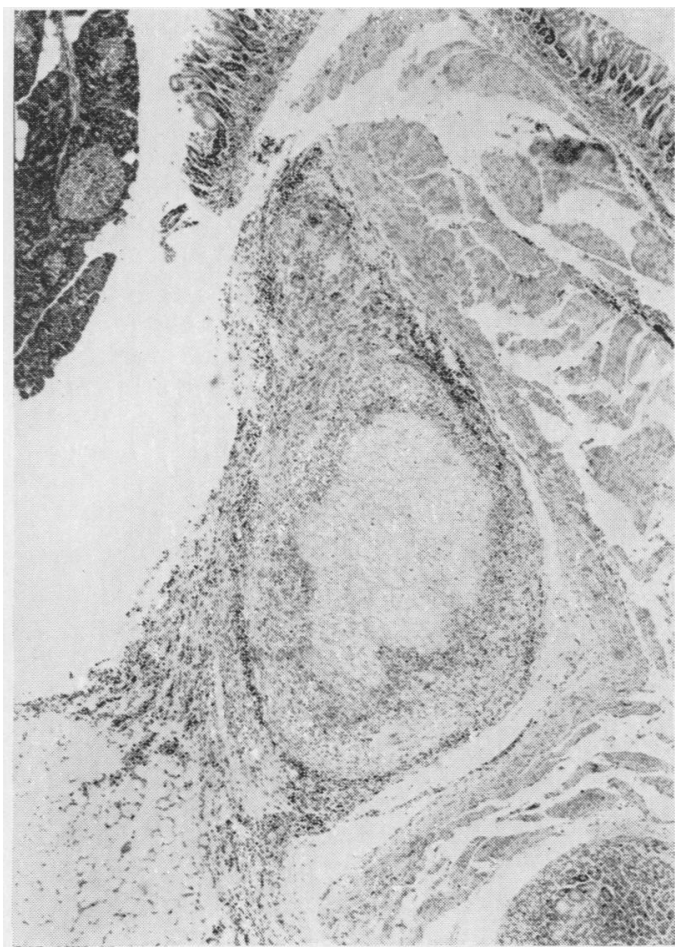

FIG. 2.-Peritoneal granuloma after 42 days. Stained with haematoxylin and eosin, $\times 30$ approximately.

through the larynx into the lungs of rats. Death results from acute oedema of the lungs. Given intraperitoneally to cavies, $100 \mathrm{mg}$. killed two of six animals within a short time, but $50 \mathrm{mg}$. was tolerated well.

It appears further that zinc stearate disappears within a period of about a fortnight from the lungs of rats, presumably by processes of phagocytosis and solution. It is therefore not surprising that no fibrosis results in the lungs of these animals after a single injection through the larynx.

In the peritoneum of cavies the powder provokes a granulomatous reaction, at first with a polymorphonuclear leucocytic response. These cells die and are surrounded, and eventually digested, by histiocytes. The stearate remains visible in the peritoneum of cavies much longer than in the lungs of rats, possibly because it is rapidly aggregated into a very few masses, and it can still be found after 42 days enclosed in a ring of histiocytes outside which is a narrow zone of fibroblastic activity. However, somewhere between the 42nd and the 100th days the stearate disappears and the granulomatous process regresses until no sign of it can be found.

These experiments, then, while suggesting that inhalation of zinc stearate might produce acute inflammation of the upper respiratory tract or of the lungs, provide no evidence of any fibrogenic permanent effect. Indeed, its solubility suggests that such an effect is unlikely to occur. 
Summary

Industrial zinc stearate dust in suspension is acutely irritant when injected into the lungs of rats or the peritoneum of cavies.

No fibrosis has resulted from single injections into the lungs of rats or the peritoneum of cavies. Foreign-body granulomata were present for several weeks in the peritoneum but ultimately resolved.

I am grateful to Dr. A. I. G. McLaughlin, H.M. Medical Inspector of Factories, for drawing my attention to the report of Noro and Uotila, for trying to obtain further information from Dr. Noro, and for helping to obtain the sample of zinc stearate. The photomicrographs were taken by Mr. A. W. Collins, F.I.M.L.T.

The expenses of this investigation were met by a grant from the Research Fund of the South-West Metropolitan Regional Hospital Board.

\section{REFERENCES}

Committee on Accidents from Zinc Stearate Dusting Powders (1925).

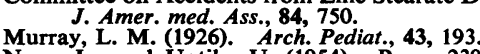

Noro, L., and Uotila, U. (1954). Paper 239, XI Internat. Congr.

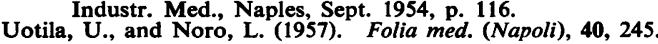

\section{Welfare at Wall's}

The practice of preventive medicine to benefit not only the people initially concerned but also the thousands who eat Wall's ice cream, pies, and sausages is the key to the welfare and medical departments recently opened at Wall's factory at Godley, near Hyde, Cheshire.

The medical department, which is under the direction of Dr. Geoffrey Fletcher, has the usual consulting and treatment rooms, well designed and equipped, surgery, and $x$-ray room. Also, the building contains a bacteriological laboratory in which it is planned to add research in industrial medicine to the routine tests necessary in a food factory.

One of the most important tasks in the medical supervision of those handling food is to ensure care of the hands. By an intensive campaign workers are being trained to report even the most trivial cut or abrasion which is cleaned and one of the department's dressings put on in the surgery. Also, if a worker cuts her hand at home (a high proportion of the workers at Godley are women) the charge hand is trained to spot an unsuitable dressing and send the patient to the medical department to have it exchanged for an approved one. The medical officer has taken great pains to ensure that dressings are suitable for workers on wet and on dry processes, that they are of a pattern which can be securely fastened to the finger or hand, and are distinctive.

All new employees have a medical interview, and also those returning after an illness. In cooperation with family doctors certain treatments are continued during working hours, and cases of sudden illness at work are referred to them also.

\section{A Human View of a Great Port}

\section{W. GOLDBLATT}

It is characteristically Italian that even so apparently a workaday subject as the industrial medical problem of work in docks, including its physiopathological, clinical, and preventive aspects should be presented in this book* with covers showing a detail of Bordone's seventeenthcentury picture of the port of Genoa in colour. This beautiful picture, which resembles a kind of aerial abstract of the conception one has of old Genoa, inevitably tells us that, even in those far-off days, a great port involved almost every working activity which man must undertake. The congestion of dwellings, storehouses, building and repair shops, administration and commercial buildings, guildhalls, loading and unloading quays, breakwaters, ships big and small, coming and going, landing stages, all combine to present to us a world, at once beautiful, vital, questing and, in every sense, bigger than man, its creator, himself. In this picture by Bordone we realize the time when the quest had to be undertaken in the hard way. If, today the way is different, mechanized, quick, massive, it nevertheless remains hard. In almost every field of activity embraced in the term dock work the call upon qualities of strength, judgment, expertise, courage, skilful cooperation, and responsibility is more insistent today than it was in those early days.

Dock work entails a peculiarly strong sense of responsibility. The loader in the hold knows he endangers the sailor if careless; the pump operator knows the life, of the underwater man depends on him; the crane operator can maim a stacker ; the port doctor knows he endangers the population if he is too facile in lowering the Yellow Jack; the industrial doctor knows he must be rigid in his standards of acceptance for work, more so indeed, than in most other industries; the loader on shore knows that careless handling of drums, kegs, and other containers may subject his opposite number at a port of call in dangers, toxic or dermatitic; the welder in dry dock knows that on the effectiveness of his weld depend the lives and property of many people. Like miners, dock workers have something different about them. In modern times some degree of travel has come within the means of most people in Britain, but even in Britain the dock worker gets to know more about foreign lands and peoples than do the generality of workers. In the great ports of Europe every tongue and every kind of face and dress are daily heard and seen, so that the dock worker inevitably acquires a cosmopolitan outlook and gets to know what happens in his field of work or interest abroad. There is a sense of importance and immediacy in the efforts of a dock worker which is different from that

* Il Lavoro Portuale (Dock Work). By Francesco Molfino and Damiano Zannini. (Pp. 319+index; illustrated.) Milano: Edizione I.N.A.I.L. 1956. 